\title{
Impact of Digital Education model on Mental Health of Undergraduate Dental Students during COVID-19 Lockdown
}

\author{
Kunal Raj Khanna ${ }^{1}$, Narinder Singh ${ }^{1}$, Dr. Kanu Jain ${ }^{2 *}$
}

${ }^{1}$ BDS Undergraduate Student, Maharaja Ganga Singh Dental College and Research Centre, Sri Ganganagar, Rajasthan, India

${ }^{2}$ MDS, Department of Oral Pathology and Microbiology, Maharaja Ganga Singh Dental College and Research Centre, Sri Ganganagar, Rajasthan, India

DOI: $10.36347 /$ sjds.2020.v07i08.002

| Received: 19.08.2020 | Accepted: 27.08.2020 | Published: 30.08.2020

*Corresponding author: Dr. Kanu Jain

Abstract

Original Research Article

Background: The students all around the world are suffering a major impact of COVID-19 Lockdown on their course studies. This stress and associated fears in turn have affected their mental health. This study was done with an aim to evaluate the effect of digital education model used during COVID-19 lockdown on the professional learning and mental health of undergraduate dental students of India. Materials and Methods: A questionnaire including 31 items was designed and circulated to undergraduate dental students in different parts of the country through different dental forums and groups. All the participants submitted their response through the link for questionnaire generated in Google forms. Two separate sections of the questionnaire evaluated impact of nationwide lockdown on professional learning and its effects on mental health of students. Results were analysed through descriptive statistics. Results: A total of 232 students responded to the questionnaire. Most of the participants felt that COVID-19 lockdown is impacting their professional learning in a great way. Majority of them are suffering from the fears regarding their examinations, clinical practice and dentistry as a future career. All these fears are impacting their mental health as reflected in the changes in their daily routine. Conclusion: COVID-19 lockdown is having a massive impact on the professional learning of undergraduate dental students in India. As most of students are facing a deterioration in their mental health due to their fears, there is a dire need of advocation of psychological counselling to students.

Keywords: COVID-19, Dental students, Learning, Lockdown, Mental health, Professional.

Copyright @ 2020: This is an open-access article distributed under the terms of the Creative Commons Attribution license which permits unrestricted use, distribution, and reproduction in any medium for non-commercial use (NonCommercial, or CC-BY-NC) provided the original author and source are credited.

\section{INTRODUCTION}

Novel corona virus disease (COVID-19) was first reported in city of Wuhan in China, where the outbreak first emerged in late 2019 [1]. Due to the lack of knowledge, less precautionary measures were taken on time and as a result of which, the virus spread very aggressively over the whole world. The first case in India was reported on 30 January 2020 resulting in the lockdown of the whole country in March 2020. Not only malls, cinemas, restaurants, transportation system but all educational institutions including colleges, schools, private and government sectors were shut down in no time [2].

A great impact has also occurred on students who were staying in hostels while under taking professional courses. When a nationwide lockdown was declared, students had to leave hostels in a hurry and had to travel back home in the middle of their course session. This not only affected their learning but also took a toll on the their mental health too. The entire educational system came to a halt and as a result many students lost the track of their studies. To tackle this problem universities and colleges started classes for students through digital platform [3]. The most difficult part for students was to adapt to the new digital educational system as this was something new for them and no time was available to become familiar.

Dental colleges follow a dedicated pattern of study divided into two parts, theoretical and practical. The theoretical part was completed on the virtual stage with less challenges as compared to practical section which is the most important part in the medical side of the world as it includes the evaluation of the patients where physical presence is must. A focus is thus needed on the medical field, especially dental colleges which are massively affected during this pandemic and the difficulties which the dental students are going through. Thus keeping these problems in mind, this study was undertaken with an aim to evaluate the impact of COVID-19 lockdown on professional learning and mental health of undergraduate dental students in India. 


\section{MATERIAL AND METHODS}

This study highlighting the problems faced by dental students during the COVID 19 outbreak was conducted through a set of questions. A structured questionnaire was designed at Google forms including consent from participants. The online survey link was circulated via different social media platforms. It was sent on dental whatsapp groups, by texts and emails. The response received from participants was collected through an online survey submission. Dental students through out the country were included for the study. The questionnaire consisted of total 31 items which were divided into two sections. The first section focused on the evaluation of professional learning and second section was designed to know about the impact on the mental health due to the lockdown in pandemic. A total of 232 Bachelor of Dental Sciences (BDS) students from different colleges across country participated in this survey and submitted their valuable answers. The data was analysed through descriptive statistics and was presented in tabular form.

\section{RESULTS}

A total of 232 students from 14 different states of India submitted the completed questionnaire with a total of 31 questions which were based on 'Professional learning and mental state evaluation' of dental students during COVID-19 Lockdown. The response were listed from various states as follow: Uttar Pradesh (67), Rajasthan (56), Haryana (34), Bihar (26), West Bengal (19), New Delhi (6), Karnataka (5), Maharashtra (5), Uttarakhand (3), Odisha (4), Jammu and Kashmir (2), Jharkhand (2), Madhya Pradesh (2), Assam (1)

The demographic information of the students is presented in Table-1. In Table-2, there is a description about the percentages of students having an impact on their professional learning due to COVID-19 lockdown. In Table-3, information regarding evaluation of the ways in which this lockdown has affected the professional learning of dental students is presented.

In Table-4, results related to percentages of students with affected mental state during lockdown. In Table-5, results pertaining to exploration of the ways by which mental health of students is affected is presented.

Table-1: Demographic characteristics of the respondents

\begin{tabular}{|c|l|l|l|}
\hline Variable & Component & N & Percentage \\
\hline 1. Age & $17-21$ years & 159 & $68.53 \%$ \\
\hline & $22-25$ years & 73 & $31.46 \%$ \\
\hline 2. Gender & Male & 64 & $27.57 \%$ \\
\hline 3. Level of Education & Female & 168 & $72.41 \%$ \\
\hline & BDS First Year & 87 & $37.50 \%$ \\
\hline & BDS Second Year & 88 & $37.93 \%$ \\
\hline & BDS Third Year & 44 & $18.97 \%$ \\
\hline & BDS Final Year & 13 & $5.60 \%$ \\
\hline Location & Rajasthan & 56 & $24.13 \%$ \\
\hline & Delhi & 06 & $2.5 \%$ \\
\hline & Uttar Pradesh & 67 & $28.87 \%$ \\
\hline & Karnataka & 5 & $2.1 \%$ \\
\hline & Bihar & 26 & $11.2 \%$ \\
\hline & West Bengal & 19 & $8.18 \%$ \\
\hline & Uttarakhand & 03 & $1.29 \%$ \\
\hline & Jammu and Kashmir & 02 & $0.86 \%$ \\
\hline & Haryana & 34 & $14.6 \%$ \\
\hline & Odisha & 04 & $1.72 \%$ \\
\hline & Maharashtra & 05 & $2.15 \%$ \\
\hline & Assam & 01 & $0.43 \%$ \\
\hline & Jharkhand & 02 & $0.86 \%$ \\
\hline & Madhya Pradesh & 02 & $0.86 \%$ \\
\hline & &
\end{tabular}


Table-2: Impact on professional learning of dental students

\begin{tabular}{|l|l|l|l|l|l|}
\hline S. No & Question & $\begin{array}{l}\text { N } \\
\text { (Yes) }\end{array}$ & $\begin{array}{l}\text { Percentage } \\
\text { (Yes) }\end{array}$ & $\begin{array}{l}\text { N } \\
\text { (No) }\end{array}$ & $\begin{array}{l}\text { Percentage } \\
\text { (No) }\end{array}$ \\
\hline 1 & Is lockdown affecting your studies? & 197 & $84.91 \%$ & 35 & $15.09 \%$ \\
\hline 2 & Are you taking online classes? & 195 & $84.05 \%$ & 37 & $15.95 \%$ \\
\hline 3 & Is Online learning similar to classroom studies? & 39 & $16.81 \%$ & 193 & $83.91 \%$ \\
\hline 4 & $\begin{array}{l}\text { Are there any advantages of online classes over classroom } \\
\text { studies? }\end{array}$ & 80 & $34.48 \%$ & 152 & $65.52 \%$ \\
\hline 5 & Are there any disadvantages of online learning? & 199 & $85.78 \%$ & 33 & $14.22 \%$ \\
\hline 6 & Are you worried about completion of syllabus? & 188 & $81.03 \%$ & 44 & $18.97 \%$ \\
\hline 7 & $\begin{array}{l}\text { Are you worried about learning of practical/clinical aspects } \\
\text { of your course? }\end{array}$ & 226 & $97.41 \%$ & 06 & $2.59 \%$ \\
\hline 8 & Are you expecting a flexible marking evaluation in exams? & 191 & $82.33 \%$ & 41 & $17.67 \%$ \\
\hline 9 & $\begin{array}{l}\text { Would it be difficult to adapt back into college atmosphere } \\
\text { when lockdown is over? }\end{array}$ & 176 & $75.86 \%$ & 56 & $24.14 \%$ \\
\hline 10 & Will it have Impact on dentistry as your career? & 174 & $75.00 \%$ & 58 & $25.00 \%$ \\
\hline
\end{tabular}

Table-3: Ways in which professional learning is impacted during COVID-19 Lockdown

\begin{tabular}{|l|l|l|l|}
\hline S. No & Question & Frequency (Yes) & Percentage \\
\hline 1. & Greatest advantage of learning through online class? & $\mathrm{N}=80$ & \\
& Better from home & 29 & $36.25 \%$ \\
& Pay more attention due to less distraction & 17 & $21.25 \%$ \\
& Saves times & 22 & $27.50 \%$ \\
& Others & 12 & $15.00 \%$ \\
\hline 2. & Disadvantage of online classes? & $\mathrm{N}=199$ & \\
& Less understanding of lecture & 51 & $25.62 \%$ \\
& Technical difficulties & 83 & $41.70 \%$ \\
& Headaches/strains & 60 & $30.15 \%$ \\
& Others & 05 & $2.50 \%$ \\
\hline 3. & Most probable reason for difficulty in adapting back to college? & $\mathrm{N}=176$ & \\
& Loss of familiarity with class room studies & 41 & $23.29 \%$ \\
& Fear of contracting COVID-19 & 112 & $63.63 \%$ \\
& Effect on future dental practice & 18 & $10.22 \%$ \\
& Others & 05 & $2.84 \%$ \\
\hline 4. & Biggest fear during this lockdown? & $\mathrm{N}=232$ & \\
& Failure in university examination & 48 & $20.69 \%$ \\
& Lack of clinical learning & 123 & $53.02 \%$ \\
& Effect on future dental practice & 35 & $15.09 \%$ \\
& Others & 26 & $11.21 \%$ \\
\hline 5. & How would it affect your career? & $\mathrm{N}=232$ & \\
& No good dental practice & 117 & $50.43 \%$ \\
& Not be able to pursue dental as career & 13 & $5.60 \%$ \\
& Might rethink about career options & 15 & $6.77 \%$ \\
& Others & 87 & $37.50 \%$ \\
\hline
\end{tabular}

Table-4: Impact on mental health of dental students

\begin{tabular}{|l|l|l|l|l|l|}
\hline S. No & Question & N (Yes) & Percentage (Yes) & N (No) & Percentage (No) \\
\hline 1 & Is it affecting your mental health? & 174 & $75.00 \%$ & 58 & $25.00 \%$ \\
\hline 2 & Is it affecting your daily routine activities? & 190 & $81.90 \%$ & 42 & $18.10 \%$ \\
\hline 3 & Are you experiencing Headache? & 156 & $67.24 \%$ & 76 & $32.76 \%$ \\
\hline 4 & Are you having neck sprain/backaches? & 92 & $39.66 \%$ & 140 & $60.34 \%$ \\
\hline 5 & $\begin{array}{l}\text { Have you observed any changes in eating } \\
\text { pattern? }\end{array}$ & 142 & $61.21 \%$ & 90 & $38.79 \%$ \\
\hline 6 & $\begin{array}{l}\text { Are you facing any sleeping disturbances? } \\
\text { Do you feel the need for professional } \\
\text { counselling? }\end{array}$ & 144 & $62.07 \%$ & 88 & $37.93 \%$ \\
\hline 7 & $56.03 \%$ & 102 & $43.97 \%$ \\
\hline
\end{tabular}


Table-5: Ways in which mental health is affected during COVID-19 Lockdown

\begin{tabular}{|c|c|c|c|}
\hline S. No & Questions & Frequency (Yes) & Percentage \\
\hline 1. & $\begin{array}{l}\text { What is your most prominent emotion in lockdown? } \\
\text { Depression } \\
\text { Anxiety } \\
\text { Worried and Afraid } \\
\text { Confused } \\
\text { Irritable } \\
\text { Angry } \\
\text { Hopeless and helpless } \\
\text { Others }\end{array}$ & $\begin{array}{l}\mathrm{N}=174 \\
17 \\
21 \\
52 \\
16 \\
13 \\
07 \\
19 \\
29\end{array}$ & $\begin{array}{l}9.77 \% \\
12.06 \% \\
29.88 \% \\
9.19 \% \\
7.47 \% \\
4.02 \% \\
10.9 \% \\
16.66 \%\end{array}$ \\
\hline 2. & $\begin{array}{l}\text { What are the change in your eating pattern? } \\
\text { Eating More } \\
\text { Eating Less } \\
\text { Eating Irregularly } \\
\text { Others }\end{array}$ & $\begin{array}{l}\mathrm{N}=142 \\
42 \\
28 \\
67 \\
5\end{array}$ & $\begin{array}{l}29.57 \% \\
19.07 \% \\
47.18 \% \\
3.5 \%\end{array}$ \\
\hline 3. & $\begin{array}{l}\text { What kind of sleep Disturbances are you facing? } \\
\text { Lack of sleep } \\
\text { Change in sleeping time } \\
\text { Sleeping more than normal } \\
\text { Others }\end{array}$ & $\begin{array}{l}\mathrm{N}=144 \\
17 \\
62 \\
42 \\
23\end{array}$ & $\begin{array}{l}11.80 \% \\
43.05 \% \\
29.16 \% \\
15.09 \%\end{array}$ \\
\hline 4. & $\begin{array}{l}\text { How are you coping up with these fears? } \\
\text { By talking with parents } \\
\text { By talking with friends/classmates } \\
\text { By discussing with your teacher } \\
\text { Taking help from online forums } \\
\text { Unable to cope up } \\
\text { Others }\end{array}$ & $\begin{array}{l}\mathrm{N}=232 \\
55 \\
67 \\
15 \\
10 \\
39 \\
46\end{array}$ & $\begin{array}{l}23.71 \% \\
28.88 \% \\
6.47 \% \\
4.31 \% \\
16.81 \% \\
19.83 \%\end{array}$ \\
\hline 5. & $\begin{array}{l}\text { How professional counselling can help you in this crisis? } \\
\text { Will help in alleviation of fears } \\
\text { In finding ways to cope up with these fears } \\
\text { In understanding of current problem } \\
\text { Will help in better preparation of future challenges } \\
\text { Others }\end{array}$ & $\begin{array}{l}\mathrm{N}=130 \\
33 \\
15 \\
24 \\
41 \\
14\end{array}$ & $\begin{array}{l}25.38 \% \\
13.84 \% \\
18.46 \% \\
31.53 \% \\
10.76 \%\end{array}$ \\
\hline
\end{tabular}

\section{DISCUSSION}

On 22 March 2020, a nationwide lockdown was ordered by Government of India, limiting the movement of entire population of country as a preventive measure against the COVID 19 pandemic. Unfortunately, this lockdown came into execution when the dental students were near the end of their respective professional year of dental studies. All colleges and universities were shut down as per the government rule, forcing the students to leave their colleges and go back to their homes [4]. To overcome the problem of syllabus completion, online classes were introduced. The present study evaluated the professional learning amongst undergraduate dental students during COVID19 lockdown and its impact on their mental health. As far as we know, this is the first study from India to evaluate the problems faced by undergraduate dental students because of COVID-19 lockdown.

Number of female respondents (168) was high as compared to male respondents (64). About one-third of the respondents belonged to 17-21years of age while remaining were from age group of 22-25years. The study revealed that more number of BDS first year students $(37.50 \%)$ and second year students (37.93\%) responded as compared to BDS third year (18.97\%) and final year students $(5.60 \%)$. The most probable reason could be that newly admitted students in their first year face more problems as they have a total new environment to live and struggle with homesickness. Moreover, students have to learn a lot of new things in a short time, sit for tough exams and face the fear of failing. The direct contact with patients, witnessing the emotional stress and breakdowns, seeing wounds and operating on real human bodies is enough to stress out students. As the students pass through initial struggling years and reach their final year, they gain the experience of tackling all the problems, hence a better time management can be observed in the final year students [5]. The questionnaire was circulated to the dental students throughout the country to get a better view. The country was divided into five regions and according to the region, we observed the maximum participants were from central India (100) followed by west (56), north (42), south (33) and eastern region (01).

The study revealed that a great number of participants $(84.91 \%)$ are feeling the impact of this lockdown on their studies. Though quite a great 
percentage of them $(84.05 \%)$ are attending online classes provided by the colleges, almost two-third of them feel that learning from online classes is not of much help. Out of few students $(16.8 \%)$ who feel that online classes have some advantages, learning from comfort of home and saving on time are the chief reasons. Others feel that they can pay more attention in online lectures due to less distraction.

Instead majority of students $(85.78 \%)$ feel online learning has disadvantages over classroom teaching. The prime cause is the technical difficulties faced followed by headaches or strain experiences and less understanding of the lectures. These could be attributed to the fact that dentistry is one professional course that cannot be taught from the distance. There is very less interaction in the virtual class with an additional problem of internet connection and limited number of platforms to conduct online meetings. Long exposure to the harmful rays released by the mobiles phone and the computer screen can cause headaches, backaches, sprain and strain on eyes [6]. Not able to properly clear their doubts due to virtual interaction with teachers along with not able to perform clinical part of the course are adding hay to fire.

With these issues in course learning, there is a rise of stress and fears amongst students. As in present study, most of the students $(81.07 \%)$ are worried about syllabus completion while a large percentage $(97.41 \%)$ have worries regarding learning of practical or clinical aspects of course. As dental curriculum comprises of huge numbers of study hours including both theory lectures and clinical postings where physical presence of patients is must, the lockdown has come as a major obstacle to learn both aspects. Due to barriers in the learning process, most of the students $(82.33 \%)$ feel the need of a flexible marking in the evaluation of their examinations in future. Not only this, one-third of them feel that it would be very difficult for them to adapt back into their college atmosphere once this lockdown is over. Majority of them are fearful of contracting COVID-19 from the patients as dental diagnosis requires physical examination of patients. Some of them think that by the time they will reach back to their respective colleges, they would have lost the familiarity with classroom studies. Few of them are having fear that the crisis will affect their future dental practice as the colleges are shut due to lockdown and they are not able to get experience of working on the patients.

Though lack of clinical learning remains the biggest fear amongst most of the students, others fear of losing a year due to failure in university examination. Few have the fear of suffering a big blow to their dental practice in future. Owing to these problems, one-third of students feel that this is going to put a great impact on the dentistry as their future career. Half of them think that they would not be able to establish a good dental practice, minority of them think that they will not be able to pursue dentistry as a career altogether and will have to look for alternate career options.

One-third of participants felt that the fears regarding learning their course in this lockdown is affecting their mental health. The prominent emotion amongst majority of them is feeling of being worried and afraid $(29.88 \%)$. Some of them are mainly suffering from anxiety $(12.06 \%)$, feeling hopeless and helpless (10.09\%), depression (9.77\%), confusion (9.19\%), irritable (7.47\%) and angry (4.02\%). While $16.66 \%$ have other emotions as dominant feeling.

The effect on the mental health is reflected in the changes in their routine habits. Most of them are feeling change in eating pattern and sleep disturbances, while few are experiencing headaches, neck sprains or backaches. Majority of them are eating irregularly (47.18\%), some are consuming more food $(29.57 \%)$ while few are eating less than usual $(19.07 \%)$. Very few have adopted some different eating habit (3.5\%). Regarding the change in sleeping pattern, many of them are sleeping at different time $(43.05 \%)$, some are sleeping more than usual $(29.16 \%)$, while few are experiencing lack of sleep (11.08\%). $15.09 \%$ have some other kind of sleep disturbance. As many students were well adjusted in routine of hostel prior to lockdown, abrupt change in their routine has affected their sleeping time and eating pattern. Continuous long sitting hours in front of their mobile or computer screens for online classes in same posture and exposure to radiations by these screens everyday is causing them sprains and headaches [7]. On top of that, additional stress caused by the fears related to their studies has led to further deterioration in their mental health.

All these issues have led to further aggravation of stress. Most of the students are trying to cope up with their fears and stress by talking to their friends $(28.88 \%)$ and parents $(23.71 \%)$. Few students are discussing their problems with their teachers $(6.47 \%)$ and seeking help from online forums $(4.31 \%)$. While others are finding other means to tackle $(19.83 \%)$, some of them are not able to cope up with them at all $(16.81 \%)$. Some students find it difficult to open up about their fears to their parents as a result of gap between parents and children. Thus, some students prefer sharing their problems with the friends instead of parents. Students are unable to take help from teachers because of the lockdown. Some of them find it easier to vent it out through online forums while some students are not capable to find any help and thus find it difficult to face the challenges.

Amidst all this mental chaos, almost half of the participants feel the need for professional counselling. Majority of them feel that it will help them to prepare themselves for future challenges $(31.53 \%)$, quite a good number think that counselling will help in alleviation of their fears regarding their studies and profession 
$(25.38 \%)$ [8]. Some of them feel that counselling will help them understand the present problem in a far better way $(18.46 \%)$ while others feel that they will find the ways to cope up with these fears through counselling. $10.76 \%$ feel that professional counselling during this COVID-19 lockdown is going to help them in some way to combat their fears. The limitation of the study was low sample size as it was difficult to reach most of the students in lockdown.

From this study, we concluded that the majority of dental students are suffering from anxiety, depression and stress leading to disturbed sleep and irregular diet in COVID-19 lockdown. As they find it difficult to share their problems and find ways to cope up with their fears, providing them with psychological counselling is the great need of the hour. Moreover, there is a need for further research in this area, with greater sample size and from different regions of the country so that we are better equipped in the future to face such a situation if it arises.

\section{REFERENCES}

1. Lai J, Ma S, Wang Y, Cai Z, Hu J, Wei N, Wu J, Du H, Chen T, Li R, Tan H. Factors associated with mental health outcomes among health care workers exposed to coronavirus disease 2019. JAMA network open. 2020 Mar 2;3(3):e203976.
2. Krishnakumar B, Rana S. COVID 19 in INDIA: Strategies to combat from combination threat of life and livelihood. J Microbiol Immunol Infect. 2020;53(3):389-91.

3. Kebritchi M, Lipschuetz A, Santiago L. Issues and challenges for teaching successful online courses in higher education: A literature review. Journal of Educational Technology Systems. 2017;46(1):429.

4. Lancet T. India under COVID-19 lockdown. Lancet (London, England). 2020 Apr 25;395(10233):1315.

5. Lodge JM, Kennedy G, Lockyer L, Arguel A, Pachman M. Understanding difficulties and resulting confusion in learning: an integrated review. Front Educ. 2018; 3:49.

6. Miller AB, Sears M, Hardell L, Oremus M, Soskolne CL. Risks to health and well-being from radio-frequency radiation emitted by cell phones and other wireless devices. Frontiers in Public Health. 2019;7:223.

7. Keykhosravi A, Neamatshahi M, Mahmoodi R, Navipour E. Radiation Effects of mobile phones and tablets on the skin: A systematic review. Adv Med. 2018;2018:9242718.

8. Shaterloo A, Mohammadyari G. Students counselling and academic achievement. Procedia Social and Behavioral Sciences. 2011; 30:625-8. 